$14^{\text {th }}$ Conf. Agric. Develop. Res., Fac. of Agric., Ain Shams Univ., March, 2019, Cairo, Egypt

Special Issue, 27(1), 905 - 912, 2019

Website: http://strategy-plan.asu.edu.eg/AUJASCI/

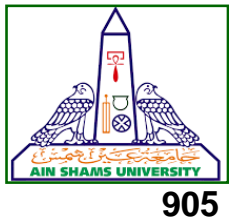

\title{
EFFECT OF IRRIGATION SYSTEMS IMPROVEMENT ON WATER UNIT PRODUCTIVITY UNDER NORTH DELTA REGION CONDITIONS OF EGYPT
}

\author{
Shaban Kh.M. ${ }^{1}$, Galal M..E. ${ }^{2}$ and Elgamal T.T. ${ }^{1}$ \\ 1. Water Management Research Institute, National Water Research Center, Giza, Egypt \\ 2. Soil Sci. Dept. Fac. of Agric., Ain Shams Univ., P.O. Box 68, Hadyek Shoubra 11241, \\ Cairo, Egypt \\ *Corresponding author: khaledsha3pan54@gmail.com \\ Received 31 December, 2018, $\quad$ Accepted 28 May, 2019
}

\section{ABSTRACT}

Several field trials and laboratory studies were conducted to evaluate the impact of the implementation of the activities and processes of the development of the field irrigation systems at ElMahmoudia area, El-Beheira Governorate, Egypt, during the successful growing seasons winter 2016/17 and summer 2017 to investigate the effect of irrigation systems improvement projects on water productivity. The measurements were conducted in a tertiary canal (Mesqa) at the head of Nekla canal (Arafa Mousa Mesqa). Water consumption values for different crops were calcaulated, and water application was calculated through calibrating the capacities of the pumps and recording the operation hours. The most important results were as follows: Applied irrigation water decreased after irrigation improvement. Applied irrigation water for wheat, rice, maize, sweet potatoes and watermelon before irrigation improvement were higher than the corresponding values after irrigation improvement by $9.0 \%, 15 \%, 11 \%, 15 \%$ and $10 \%$ respectively. The productivity of wheat, rice, maize, sweet potatoes and watermelon increased after irrigation improvement by $7.0 \%, 4.0 \%, 3.0 \%, 8.0 \%$ and $9.0 \%$ respectively. Water productivity increased after irrigation improvement, and the increase ratios for wheat, rice, maize, sweet potatoes were $14.0 \%, 16.0 \%, 13.0 \%, 20.0 \%$, and $18.0 \%$ respectively.

Key words: Irrigation development, Wheat, Rice, Maize, Sweet potatoes, Watermelon water consumptive and water productivity.

\section{INTRODUCTION}

In areas suffering from water shortage such as Egypt, irrigated agriculture lands are by far the largest consumer of water supply. Therefore, it is important to produce more food with less water. Increasing crop water productivity (CWP) is a result of less water usage and/or increasing crop yield. This decrease the gap between water supply and water demand. Zwart and Bastiaanssen, (2004) simply defined CWP as the ratio of marketable crop yield to actual evapotranspiration.

Egyptian irrigation and drainage networks consist of $20,000 \mathrm{~km}$ of canals of different dimensions and parallel to an equal drainage system (ElMarsafawi et al 2018). The main infrastructure of these networks has been expanded and modified during the long history of agriculture in the Nile Delta. As a result, there is a significant link between watercourses at all levels of distribution, including canals and drains (Molle et al 2015). In Egypt, water is distributed through sub-channels according to a rotation system which is defined as including two cycles of irrigation in the summer and three in the winter: this usually means that the canal will be 5 days "on" and 5 days "off" in summer, and 5 days "on" and 10 days "off" in winter. Water volumes are calculated based on the capacity of the canal and its estimated total water needs (Maraux et al 2004).

Irrigation Improvement Project (IIP) conducted through the Egyptian Ministry of Water Resources and Irrigation introduced many activities and processes for the development of irrigation systems in the last decade to rationalize the use of water resources. These activities included the conversion of the dusty canals to buried pipes operating under 
water pressure or canal lining, the transition from multiple lift points to a single lifting point at the mouth of the main canal system, the replacement of the hand control gates to the mechanical control gates using the Alfalfa valves for each canal feeder, in addition to the replacement of combined water lifting machines with diesel or electric lifting machines. The development of field irrigation system extended to the formation of water users' associations at the branch canal level and the water council at the main canal level.

This work was conducted to evaluate the impact of the implementation of the activities and processes of the development of the field irrigation systems on rationalizing the use of water resources and study its impact on soil and irrigation water characteristics, water productivity and yield of some of the cultivated crops.

\section{MATERIALS AND METHODS}

\section{Study Area}

The methodology of the currents study was built on comparing water unit productivity as response to irrigation system improvement under improved areas conditions. A command area in AlBehira Governorate have been selected for this purpose. Al-Behira Governorate is bordered to the north by the Mediterranean, to the east by the Rosetta branch, to the west by the Governorate of Alexandria and Matrouh, and to the south by Giza governorate, Egypt (30.63 longitude, 30.89 latitude, and $1 \mathrm{~m}$ altitude above mean sea level) during the 2016-17 and 2017.

Nekla canals was the selected, however it served an area of about 3400 feddan, and the canal is served by Kafr Amlet and El-Babli drains and its tail escape is draining in El-Atf drain are presented in Fig 1.

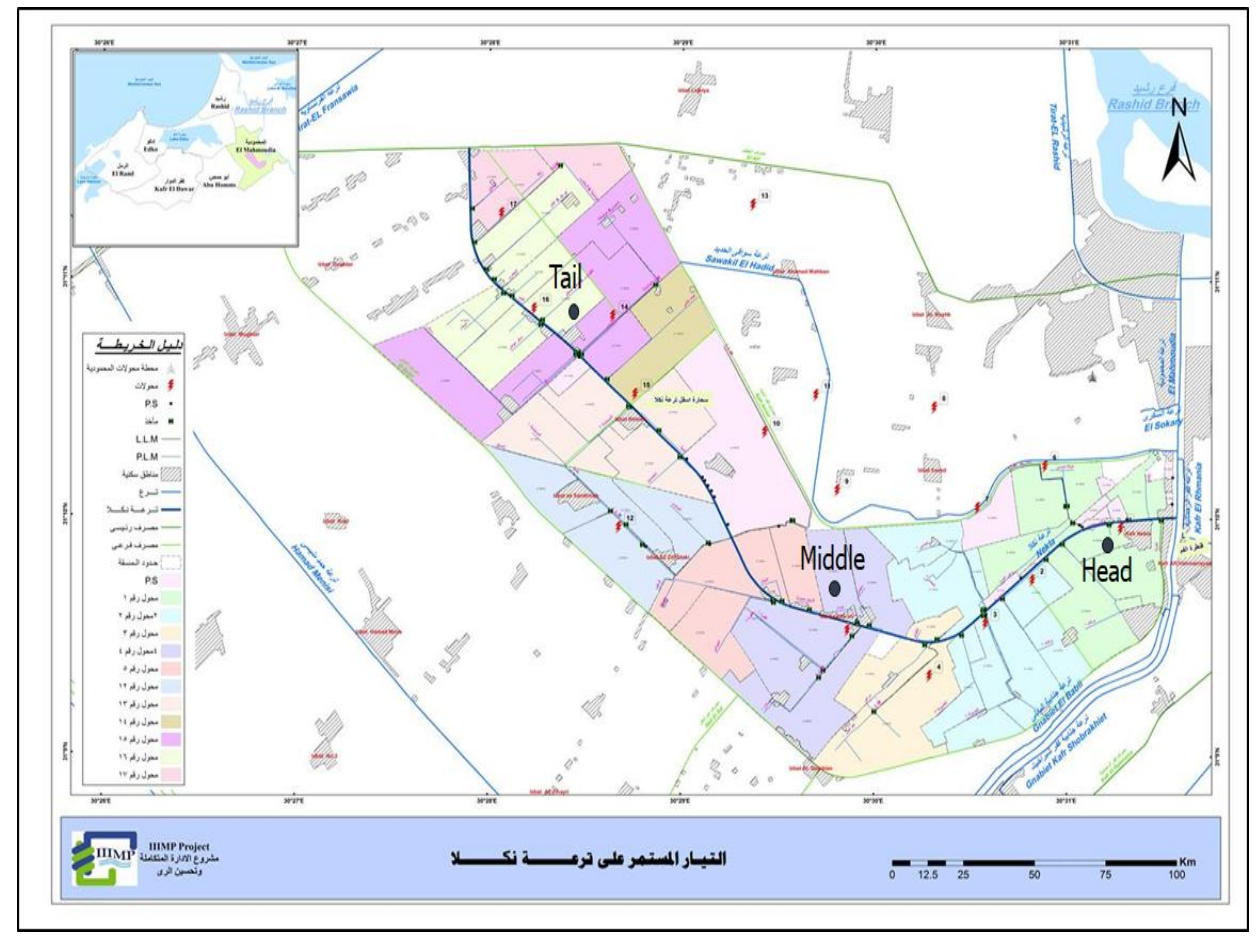

Figure 1. Nekla Location maps and layout of improved Mesqas

The canal with its secondary drains and the locations of the selected Mesqas. Weather data for the experimental site were obtained from El-Behira agro-meteorological station. Seasonally Max, Min and mean values of air temperature, relative humidity, wind speed, solar radiation, and pan evapo- ration are presented in Table 1. Soil samples from the experimental site were collected to determine main soil physical. Soil and hydro-physical properties of the studied area mechanical, analysis, were determined according to Klute (1986) and the values are listed in Tables 2 and 3, respectively. 

region conditions of Egypt

Table 1. Al-Behera micro-meteorological parameters data during winter 2016/17 and summer 2017 seasons

\begin{tabular}{|c|c|c|c|c|c|c|c|c|c|}
\hline & & SRAD & TMAX & TMIN & RAIN & WIND & TDEW & TMEAN & RH \\
\hline Winter & Max & 23.66 & 29.52 & 16.33 & 68.08 & 5.90 & 11.37 & 22.17 & 63.50 \\
$\mathbf{2 0 1 6 -}$ & Min & 10.4 & 17.6 & 6.0 & 0.0 & 3.1 & 3.5 & 10.9 & 43.5 \\
$\mathbf{2 0 1 7}$ & Ave & 16.32 & 23.60 & 10.56 & 9.73 & 4.14 & 7.04 & 16.27 & 55.69 \\
\hline \multirow{2}{*}{ Summer } & Max & 29.6 & 38.6 & 22.2 & 0.0 & 3.0 & 16.7 & 29.9 & 47.4 \\
$\mathbf{2 0 1 7}$ & Min & 23.58 & 30.47 & 15.47 & 0.00 & 1.20 & 9.40 & 22.17 & 39.09 \\
& Ave & 27.3 & 35.2 & 19.3 & 0.0 & 1.7 & 13.1 & 26.8 & 42.7 \\
\hline
\end{tabular}

Table 2. Soil mechanical analysis at the experimental site

\begin{tabular}{|c|c|c|c|c|}
\hline Class profile depth & Sand $(\%)$ & Silt $(\%)$ & Clay $(\%)$ & Texture class \\
\hline $0-15$ & 13.8 & 31.0 & 55.2 & Clayey \\
$15-30$ & 20.9 & 34.3 & 44.8 & Clayey \\
$30-45$ & 21.7 & 38.7 & 39.6 & Clayey \\
$45-60$ & 22.1 & 39.7 & 38.2 & Clayey \\
\hline
\end{tabular}

Table 3. Hydro-physical analysis of the soil at the experimental site

\begin{tabular}{|c|c|c|c|c|}
\hline $\begin{array}{c}\text { Soil depth } \\
(\mathbf{c m})\end{array}$ & $\begin{array}{c}\text { Field capacity } \\
(\%)\end{array}$ & $\begin{array}{c}\text { Permanent wilt- } \\
\text { ing (\%) }\end{array}$ & $\begin{array}{c}\text { Available soil Water } \\
(\%)\end{array}$ & $\begin{array}{c}\text { Bulk density } \\
\left(\mathbf{g} / \mathbf{c m}^{\mathbf{3}} \mathbf{)}\right.\end{array}$ \\
\hline $0-15$ & 46.70 & 25.38 & 21.33 & 1.10 \\
$15-30$ & 40.35 & 21.93 & 18.42 & 1.15 \\
$30-45$ & 37.15 & 20.19 & 16.96 & 1.24 \\
$45-60$ & 34.20 & 18.59 & 15.61 & 1.32 \\
\hline
\end{tabular}

\section{Studied Crops}

Egypt has several perennial crops that grow all year where field crops are planted mainly in two or three seasons: winter (October through April), summer (May through September), and sometimes in the Nile season (July through October). Tested winter crops include wheat, clover, and winter vegetables (sweet potatoes). Tested summer crops include maize, rice, and summer vegetables (watermelon).

\section{Measurements and calculation}

The main activities in this study were calculating water application through calibrating pumps and collecting/recording operation hours and calculating water consumption and then water productivity for different crops.

\section{1- Irrigation water applied}

Irrigation water applied and water availability, water is almost available continuously in Nekla canal and due to its steep slope, water is reaching the tail end easily. As mentioned above, and based on (El-Fetyany, 2016), there was an adequacy of water all over the canal. Water application at Mesqa / field level is calculated based on the discharge from the pumps and the operation hours of this pump. The following two sub-sections describe both points:

\section{2- Pump calibration}

In improved Mesqas, the ultrasonic flow meter is used to measure the discharge, with reflective type (V). In type (V), both transducers mounted on one side of the pipe, and the distance between them is defined based on the characteristics of the pipelines and the measured liquid. The flow is recorded in (lit/sec). The flow from the pump depends on the pressure (head), and the pressure consists of suction head and delivery head. Suction head is related to the water level in the suction side. Delivery head depends mainly on the friction losses, and therefore, it depends on the opened valve(s). The head is measured around the pumps (suction and delivery heads) for different scenarios of opening 
valves to define the range of the flow from the pumps.

\section{Collecting/recording operation hours}

With the flow from the pump, the operation hours should be collected/ recorded to define total water supply from the Mesqa. The simple way to get the operation hours is to collect them manually. The operator of the Mesqa record the daily starting and stopping hours of the pumps. Other time, advanced techniques are used to define such starting and stopping hours. A data logger that is connected to the electric circle is used for this purpose. The device is recording the situation (on/off) each time interval. The recorded data is analyzed to define the starting and the stopping time for each pump such recorded data.

\section{3- Water consumptive use}

Water consumptive use (CU), or actual evapotranspiration $(\mathrm{ETa})$, values were determined by Time Domain Reflectometry (TDR) sensor, which measured the volumetric soil moisture contents in the surface $0.6 \mathrm{~m}$ depth of soil before and after each irrigation. The TDR is widely used to measure soil-water content according to (Cataldo et al. 2011). The $C U$ values of the depth $60 \mathrm{~cm}$ were calculated according to Hansen et al. (1979) using the following equation:

$$
\mathrm{CU}=\sum_{i=1}^{\mathrm{n}} \mathrm{D}_{\mathrm{i}} * \mathrm{D}_{\mathrm{bi}} * \frac{\mathrm{PW}_{2}-\mathrm{PW}_{1}}{100}
$$

Where:

$\mathrm{CU}=$ water consumptive use $(\mathrm{cm})$ in the effective root zone $(60 \mathrm{~cm})$.

$D_{i}=$ soil layer depth $(15 \mathrm{~cm})$.

$D_{b i}=$ soil bulk density, $\left(\mathrm{g} / \mathrm{cm}^{3}\right)$ for this depth.

$\mathrm{PW}_{1}=$ gravimetric soil moisture percentage before irrigation.

$\mathrm{PW}_{2}=$ gravimetric soil moisture percentage, 48 hours after irrigation.

$n=$ number of soil layers $(i=1-4)$.

\section{4- Water unit productivity}

Gross inflow is the total amount of water flowing into the field from rainfall and surface and subsurface sources. Net inflow is the gross inflow plus any changes in storage. If water is removed from storage over the time period of interest, net inflow is greater than gross inflow; if water is added to storage; net inflow is less than gross inflow. Net inflow water is either depleted, or flows out of the field of interest. Water Productivity (WP) is a simple ratio between the biological yield impressed in $\mathrm{kg}$ per $\mathrm{m}^{2}$ and (water in $\mathrm{m}^{3} / \mathrm{fed}$. as stated the following equation (El-Bably et al (2015)

Water productivity $=\frac{\text { Yield }\left(\frac{\mathrm{kg}}{\mathrm{m}^{2}}\right)}{\text { Water use or ETactual }\left(\frac{\mathrm{m}^{3}}{\mathrm{~m}^{2}}\right)}$

\section{RESULTS AND DISCUSSION}

\section{1- Water -crop consumption (CWC) and sea- sonal crop-water (SCWU) of studied crops.}

Seasonally Water consumptive use WCU values as affected by amounts of applied irrigation water in head, middle and tail Mesqa on wheat, rice, maize, sweet potatoes and watermelon are presented in Table 4. Results indicated that the amount of water consumptive use for selected crops due to increasing water applied in case of head and middle Mesqa.

Regarding to WCU monthly consumptive use, the amount of water consumptive use for wheat was the monthly consumptive use is presented in Table (5). Results indicated that they started with low amount of water when wheat plants were small, then it increased gradually as wheat plants grow up and reached its peak in April, then it decreased at the end of the season with mature plants. The peak-use period usually occurs when the vegetation is abundant and temperature is high. The most probably explanation for these results is that more available soil moisture resulted from more homogeneous soil moisture due to reliable water control.

Table 4. Water consumption on different crops of Arfa Mousa Mesqa $\mathrm{m}^{3} / \mathrm{fed}$

\begin{tabular}{|c|c|c|c|c|}
\hline \multirow{2}{*}{ Crops } & \multicolumn{2}{|c|}{ Water consumption use } & \multirow{2}{*}{ Mean } \\
\cline { 2 - 4 } & Head & Middle & Tail & \\
\hline Wheat & 1419.6 & 1428.0 & 1419.6 & 1422 \\
Rice & 2973.6 & 2982.0 & 2973.6 & 2976 \\
Maize & 2429.3 & 2420.5 & 2425.5 & 2425 \\
Sweet potatoes & 1867.7 & 1861.9 & 1880.8 & 1870 \\
Watermelon & 819.0 & 844.2 & 802.2 & 822 \\
\hline
\end{tabular}

Results in Table (4) showed that seasonal actual evapotranspiration values for rice cv. Giza 177 

region conditions of Egypt

were 2973.60, 2982.0 and $2973.6 \mathrm{~m} 3 / \mathrm{fed}$. Month for the head middle and end irrigation canal respectively. While the monthly consumptive use are presented in Table (5). It can detect that the maximum Eta was in July and then decreased until harvesting. These results may be due to prevailing water control and climatic condition.

Concerning to maize crop, results indicated that, the seasonal rates of water consumption by maize plants at the head middle and end irrigation canal are presented in Table 4. Results showed that seasonal water use values were 2429.3, 2420.0 and $2425.5 \mathrm{~m} 3 / \mathrm{fed}$ for irrigated plants at the head middle and end irrigation canal, respectively (Table 4). These results demonstrate that water consumption increased as soil moisture was maintained high by frequent irrigations. The probable explanation of these results is that higher frequent irrigations provide chance for more consumption of water which ultimately resulted in increasing transpiration and evaporation from the soil surface.
Regarding to water consumptive use for sweet potatoes the highest value for monthly consumptive use of sweet potatoes was occurred during April due to the growth development and water applied throughout this period. At the end of the season the rates declined as the crop matured (Table 6). Seasonal actual evapotranspiration values for were $44.47,44.33$ and $44.78 \mathrm{~cm}$ for the head middle and end irrigation canal respectively. These results may be due to prevailing water control and climatic condition.

Concerning to water consumptive use for watermelon crop, monthly WCU value started low at the beginning of watermelon plants growing season, and increased gradually to reach its maximum value at June, as a result of the increase in vegetative growth that requires higher water consumption to plants, then it declined at maturity (Table 5). Results showed that seasonal water consumptive use values were similar to be 19.5, 20.1, and 19.1 $\mathrm{cm}$ when of water melon plants were irrigated at the head middle and end irrigation canal, respectively.

Table 5. Monthly water consumptive use of the studied crops during, the agricultural growing seasons of 2016/17 and 2017

\begin{tabular}{|c|c|c|c|c|c|c|c|c|c|c|c|c|c|c|}
\hline Crops & & Jan. & Feb. & Mar. & Apr. & May & June & July & Aug. & Sep. & Octo. & Nov. & Dec. & Seasonal \\
\hline \multirow{3}{*}{ Wheat } & Head & 4.30 & 5.11 & 8.40 & 10.60 & 2.00 & & & & & & 0.25 & 3.10 & 33.8 \\
\hline & Middle & 4.31 & 5.10 & 8.47 & 10.65 & 2.12 & & & & & & 0.25 & 3.10 & 34.0 \\
\hline & Tail & 3.99 & 5.15 & 8.51 & 10.66 & 2.18 & & & & & & 0.25 & 3.10 & 33.8 \\
\hline \multirow{3}{*}{ Rice } & Head & & & & & 13.3 & 18.3 & 23.9 & 15.3 & & & & & 70.8 \\
\hline & Middle & & & & & 13.3 & 18.5 & 23.9 & 15.3 & & & & & 71.0 \\
\hline & Tail & & & & & 13.2 & 18.5 & 24.0 & 15.1 & & & & & 70.8 \\
\hline \multirow{3}{*}{ Maize } & Head & & & & & & 2.15 & 12.42 & 21.44 & 17.32 & 4.51 & & & 57.84 \\
\hline & Middle & & & & & & 2.15 & 12.38 & 21.36 & 17.24 & 4.50 & & & 57.63 \\
\hline & Tail & & & & & & 2.15 & 12.40 & 21.41 & 17.29 & 4.50 & & & 57.75 \\
\hline \multirow{3}{*}{$\begin{array}{c}\text { Sweet pota- } \\
\text { toes }\end{array}$} & Head & & 4.03 & 9.34 & 17.74 & 13.36 & & & & & & & & 44.47 \\
\hline & Middle & & 4.05 & 9.65 & 17.48 & 13.15 & & & & & & & & 44.33 \\
\hline & Tail & & 3.98 & 9.59 & 17.84 & 13.37 & & & & & & & & 44.78 \\
\hline \multirow{3}{*}{ Watermelon } & Head & & & & & 3.85 & 8.55 & 7.14 & & & & & & 19.5 \\
\hline & Middle & & & & & 3.77 & 8.39 & 7.89 & & & & & & 20.1 \\
\hline & Tail & & & & & 3.63 & 8.48 & 7.02 & & & & & & 19.1 \\
\hline
\end{tabular}

Applied amounts of Irrigation Water (IW) and Water Unit Productivity (WP)

Table (6) showed that impact of irrigation systems improvement on the applied amounts of irrigation water and water productivity for the studied crops. In general, seasonal water consumption values for wheat, rice, maize, sweet potatoes and watermelon before and after the irrigation systems improvement which had been presented in Table 6 were 1445, 2940, 2419, 1852 and $811 \mathrm{~m}^{3} / \mathrm{fed}$, respectively.

Indicated that applied amounts of irrigation water decreased after the implementation of irrigation improvement $9.0 \%, 15,11,15$ and $10 \%$ respectively. water for wheat, rice, maize, sweet potatoes and watermelon. This was due to the accurate water resources distribution and allocation to attain sustainable agriculture (Maraux et al 2004) 
Another achievement was the increase of the yield productivity for different crops. As presented in Table (6), the yield of wheat, rice, maize, sweet potatoes and watermelon increased after the implementation of the irrigation systems improvement with about $7.0 \%, 4.0,3.0,8.0$ and $9.0 \%$ respectively.

Due to the decrease of applied irrigation water and the increase of the yield, water productivity increased for different crops. From Table 6, the obtained results indicated the water productivity increased after the implementation of irrigation improvement for the studied crops with $14.0 \%$, $16.0,13.0,20.0$ and $18.0 \%$ respectively.

The CWP observed for the wheat crop in the Shandaweel region (Upper Egypt) ranged between 0.43 to $1.44 \mathrm{kgm}^{3}$ and between 0.83 to 1.70 $\mathrm{kg} \cdot \mathrm{m}-3$ in the Giza Region of Middle Egypt (ElMarsafawy, 2018). This is lower than the CWP (close to $2.0 \mathrm{kgm}^{-3}$ ). This implies that it is probably better to grow wheat in the western Nile delta region. The obtained results were in harmony with those reported by Gao et al (2018).

\section{CONCLUSIONS}

The current study was conducted in a command area in El-Behira governorate to assess the impact of implementing irrigation systems improvement project on the increase of water productivity. The results referred to significant decrease in applied irrigation water associated in an increase in the yield of different crops, and in consequence, the water productivity for different crops increased after the implementation of irrigation improvement projects between $13 \%$ and $20.0 \%$. This maximizes the benefits of return from the unit of land and water associated from economic, environmental and social aspects.

Table 6. Water consumption, applied water, yield, water productivity and water saved under before and after development

\begin{tabular}{|c|c|c|c|c|c|c|c|c|c|}
\hline $\begin{array}{c}\text { Cropping } \\
\text { pattern }\end{array}$ & $\begin{array}{c}\text { CU Before } \\
\text { \& after Dev. }\end{array}$ & $\begin{array}{c}\text { IWA Be- } \\
\text { fore Dev. }\end{array}$ & $\begin{array}{c}\text { IWA Af- } \\
\text { ter Dev. }\end{array}$ & $\begin{array}{c}\text { yield } \\
\text { Kg/fed (Before } \\
\text { Dev.) }\end{array}$ & $\begin{array}{c}\text { yield } \\
\text { Kg/fed (Af- } \\
\text { ter Dev.) }\end{array}$ & $\begin{array}{c}\text { WP } \\
\text { Y/Et } \\
\text { before }\end{array}$ & $\begin{array}{c}\text { WP } \\
\text { Y/Et } \\
\text { after }\end{array}$ & $\begin{array}{c}\text { WP } \\
\text { Y/IWA } \\
\text { before }\end{array}$ & $\begin{array}{c}\text { W/IWA } \\
\text { Y/Iter } \\
\text { after }\end{array}$ \\
\hline Wheat & 1445 & 2176 & 1999 & 2700 & 2892 & 1.87 & 2.0 & 1.24 & 1.45 \\
Rice & 2940 & 6441 & 5592 & 4160 & 4320 & 1.41 & 1.47 & 0.65 & 0.77 \\
$\begin{array}{c}\text { Maize } \\
\text { Sweet pota- } \\
\text { toes }\end{array}$ & 2419 & 3517 & 3161 & 3863 & 4000 & 1.60 & 1.65 & 1.10 & 1.27 \\
Watermelon & 1852 & 3087 & 2692 & 10764 & 11700 & 5.81 & 6.32 & 3.49 & 4.35 \\
\hline
\end{tabular}

\section{REFERENCES}

Cataldo, A., Egidio, De. B. and Giuseppe, C. 2011. Broadband Reflectometry for Enhanced Diagnostics and Monitoring Applications. IEEE Sensors Journals 11(2), 451-459.

El-Bably A.Z., Abd El-Hafez, S.A., Mahmoud, M.A. and Samiha A.H. 2015. A New Conceptual Framework for Water Conservation Based on Addressing Water Balance, Crop Rotation and Economics. International Journal of Water Resources and Arid Environments 4(2), 120-127.

El-Fetyany M. 2016. "Assessment of Continuous Flow Application In Nekla Canal Command Area" 4th African Regional Conference on Irrigation and Drainage (ARCID), "Agricultural Land and Water Management for Sustainability under Climate Variability", Paper Code 113.
ALMAA'. International Journal of the Arab Water Council, 7(2), 41-54.

El-Marsafawy, Samia M., Swelam A. and Ghanem, A. 2018. Evolution of Crop Water Productivity in the Nile Delta over Three Decades (1985-2015). Water Journal, 10(1168), 1-12.

Gao, S., Yu, S., Wang, M., Meng, J., Tang, S., Ding, J., Li, S., and Miao, Z. 2018. Improving Water Productivity and Reducing Nutrient Losses by Controlled Irrigation and Drainage in Paddy Fields, Pol. J. Environ. Stud., 27 (3), 1049-1059.

Hansen, V.W., Israelsen, D.W. and Stringharm, Q.E. 1979. Irrigation Principle and Practices", $4^{\text {th }}$ Ed., John Wiley \& Sons, New York, USA.

Klute, A. 1986. Water retention: Laboratory methods. In: Klute, A., Ed., Methods of Soil Analy- 

region conditions of Egypt

sis, Part 1, Physical and Mineralogical Methods, ASA and SSSA, Madison, pp. 635662.

Maraux F., Scopel E. and Findeling A. 2004. Using models for optimizing soil moisture man agement strategies. Drought-resistant soils. Optimization of soil moisture for sustainable plant production: Proceedings of the Electronic Conference, 15 Nov.-18 Dec., Rome, FAO, 27p.
Molle, F., Rap, E., Ezzat Al-Agha, D., Ismail, A., Abou El Hassan, W. and Freeg, M. 2015. Irrigation Improvement Projects in the Nile Delta: promises, challenges, surprises. Water and Salt Management in the Nile delta Project Report No.4. International Water Management Institute, Water Management Research Institute, Cairo, pp. 26-46.

Zwart, S.J. and Bastiaanssen W.G. 2004. Review of measured crop water productivity values for irrigated wheat, rice, cotton and maize. In: Agricultural Water Management 69, 115133. 

المؤتمر الرابع عشر لبحوث التنمية الزراعية، ومارية

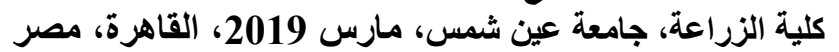

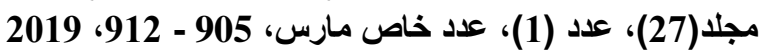

تأثير تطويرنظم الرى على إنتاجية وحدة المياه تحت ظروف منطقة شمال الدلتا بمصر

[83]

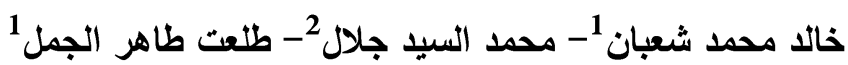 \\ 1. معهة بحوث إدارة المياه- المركز القومي لبحوث المياه- الجيزة- مصر

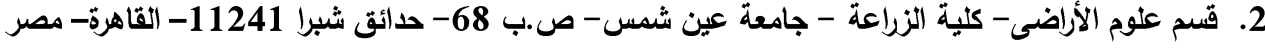

*Corresponding author: khaledsha3pan54@gmail.com

Received 31 December, 2018, $\quad$ Accepted 28 May, 2019

$$
\text { وانثتملت أهم النتائج بالدراسة على ما يلي: }
$$

انخفضت كميات الماء المضاف للحقول بعد تطبيق

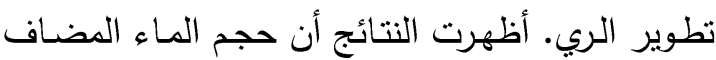

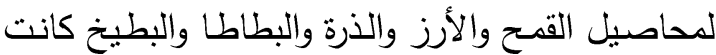

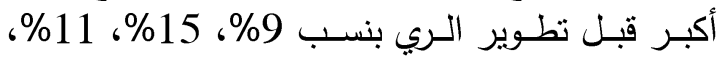
15\% \& 10 \% على التوالي.

زادت إنتاجية القمح والأرز والذرة والبط البطاط والبطيخ

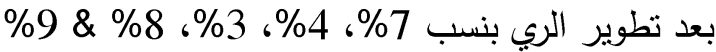

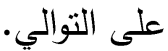
زادت إنتاجية وحدة المياه لمحاصيل القمح والأرز والذرة والبطاطا والبطيخ بنسب 14\% وحدة 16\% 16\% 13\%،

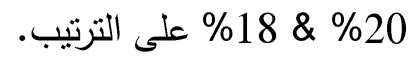

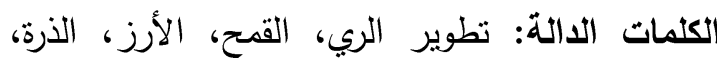
البطاطا، لب البطيخ، إستهلآك وإنتاجية المياه

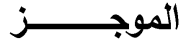

أجريت هذه الدراسة وذللك على مسقى عرفة موسى،

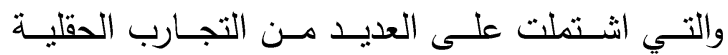

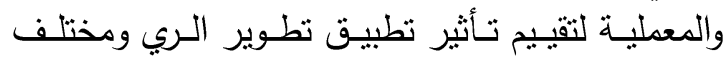
الأنثطة والممارسات الخاصة بتطوير نظم الري الحقلي

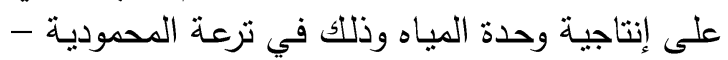

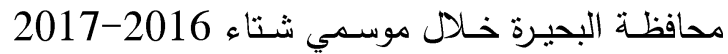

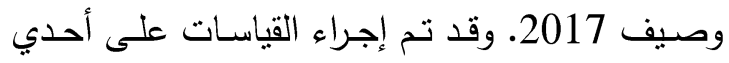

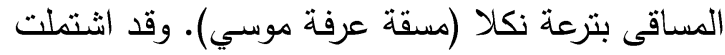

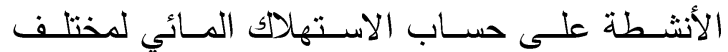

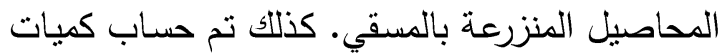

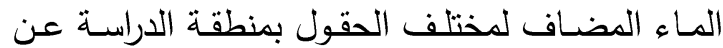

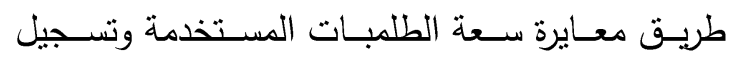
ساعات التثغيل للريات المختلفة. 